\title{
ANALYSIS OF OPEN TEXTBOOKS FOR DISCIPLINE OF SOCIOLOGY OFFERED FOR HIGH SCHOOL
}

\author{
F. K. OLIVEIRA ${ }^{1}$, K. F. ABREU ${ }^{2}$, M. F. ABREU ${ }^{3}$, R. B. CUNHA ${ }^{4}$ e A. S. GOMES ${ }^{5}$ \\ ${ }^{1,2}$ Instituto Federal de Educação, Ciência e Tecnologia do Sertão Pernambucano, ' Universidade Federal do Ceará, \\ ${ }^{4}$ Secretaria de Educação de Maracanaú, ${ }^{5}$ Universidade Federal de Pernambuco \\ francisco.oliveira@ifsertao-pe.edu.br ${ }^{1}$
}

Submitted 12/12/2016 - Accepted 15/08/2018

DOI: $10.15628 /$ holos.2018.5398

\section{ABSTRACT}

This research aimed to identify and analyze open textbooks of the discipline of Sociology offered in high school and published in Portuguese language. For this, a bibliographical research was made for better understanding of the concepts related to the open educational resources (OER), open textbooks and examples of repositories. In addition, was also performed a documentary research in National Curriculum Parameters in High School (BRASIL, 2000) and in the book Guide of the Textbook National Program (BRASIL, 2014), in order to get better understanding about the main guidelines of the offer of the discipline of Sociology to the high school. Evaluative criteria already used were adequate from the studies of Oliveira and Abreu (2016). Soon after, was conducted a survey
\end{abstract}

on the Internet to identify repositories of open textbooks and select materials from the discipline of Sociology, whose evaluation occurred by complete reading and identifying the presence or absence of evaluative criteria. It was noticed, that this work covers in part the criteria evaluated, however, are liable to adjustments and improvements. It was therefore concluded that the evaluation criteria of open textbooks considered in this research can contribute to the improvement of these materials, whether in the existing adequacy or assist the authors in the development of new materials for the generation of high quality materials, with a lower cost of production, distribution and use by Education Ministry of Brazil to serve the Textbook National Program.

KEYWORDS: Open Educational Resources, Open textbooks, Sociology Teaching.

\section{ANÁLISIS DE LOS LIBROS DIDÁCTICOS ABIERTOS DE SOCIOLOGÍA QUE SE HA OFRECIDO A LA ESCUELA SECUNDARIA}

\section{RESUMEN}

Esta investigación tuvo como objetivo identificar y analizar libros didácticos abiertos de la asignatura de Sociología ofrecidos en la escuela secundaria brasileña, publicados en lengua portuguesa. Para esto, se realizó una investigación bibliográfica para una mejor comprensión de los conceptos relacionados con los recursos educativos abiertos (REA), libros didácticos abiertos y ejemplos de repositorios. Además, se realizó una investigación documental en los Parámetros Curriculares Nacionales de la Enseñanza Secundaria (BRASIL, 2000) y en el Guía del Programa Nacional de los Libros Didácticos (BRASIL, 2014), con el objetivo de obtener una mejor comprensión sobre las principales pautas de la oferta de la asignatura de sociología a la escuela secundaria. Los criterios de evaluación ya utilizados fueron adecuados a partir de los estudios de Oliveira y Abreu (2016). Poco después, se realizó una encuesta en Internet para identificar repositorios de libros didácticos abiertos y materiales seleccionados de la asignatura de Sociología, cuya evaluación se realizó mediante una lectura completa e identificando la presencia o ausencia de criterios de evaluación. Se concluyó que este trabajo cubre en parte los criterios evaluados, sin embargo, son susceptibles de ajustes y mejoras. Por lo tanto, se concluyó que los criterios de evaluación de los libros didácticos abiertos considerados en esta investigación pueden contribuir a la mejora de estos materiales, ya sea en la adecuación existente o ayudar a los autores en el desarrollo de nuevos materiales para la generación de materiales de alta calidad, con un menor costo de producción, distribución y uso por el Ministerio de Educación de Brasil para servir al Programa Nacional de Libros Didácticos.

PALABRAS CLAVE: Recursos Educativos Abiertos, Libros didácticos abiertos, Sociología de la Educación. 


\section{INTRODUCTION}

Several projects are implemented and developed with the aim of solving problems or improving the quality of education, for example, the distribution of textbooks to students of basic education through the Textbook National Program, sale of school lunches to students, creation of full-time schools, including computers, tablets, and Internet in schools as well as developing educational software but the results don't match the investments in the area.

The tools of information and communication technology (ICT) contributed to facilitating access to content produced by people around the world, mainly because of the expansion of Internet access, and the wide range of software for the most diverse applications, including free for use and changes, whose Government policy encourages its use on machines of the Government offices to reduce costs with payments for use of software licenses (OLIVEIRA, 2010). From the principles of free LIBRE open source software (FLOSS) the open educational resources (OER) that are all essential for the development of more flexible settings of teaching and learning, being the true movers of the new teaching and learning settings.

This work, then, aimed to identify and analyze open Sociology discipline textbooks offered in high school and published in Portuguese language. The evaluative criteria of this research are based on scientific research adequacies Oliveira and Abreu (2016), which guides the competencies and skills established by the National Curriculum Parameters for high school (BRASIL, 2000) and the Guide of Textbook National Program of 2015 (BRASIL, 2014). In addition, this study adopted 5R's freedoms (MALLMAN \& JACQUES, 2015), that make up the criteria geared to OER's.

The research focused only on open textbooks published in Portuguese language, for the Sociology discipline at high school and available on Internet repositories. The evaluation of the open textbooks or not measure sought the materials evaluation criteria, covering the National Curriculum Parameters for high school and its possibilities of use, adaptation, distribution and study, according to the freedoms of OER's.

The following sections of this article will present the concepts related to research, in the second section, the methodology of the research on third, the results and discussion in the penultimate section and conclusions in the last section.

\section{LITERATURE REVIEW}

In this section, the concepts related to the topic of the research are presented, such as: open educational resources (OER), precepts of Sociology Education and National Curriculum Parameters for High School (NCPHS).

\subsection{Open Educational Resources (OER)}

Open educational resources (OER) are all essential ones for the development of more flexible settings of teaching and learning, being the real movers of the new teaching and learning settings (AMIEL, 2012; OLIVEIRA \& ABREU, 2016). 
The textbook is the main reference for disciplines of graduate, high school and other educational arrangements. This template generates a high logistical cost distribution (ORTELLADO, 2009) and acquisition, particularly in the case of the Textbook National Program (BRASIL, 2012), that thousands of copies are purchased periodically for distribution to students of high school and elementary school.

In addition, the purchase and management model of teaching material still guarantees all rights reserved to editors, being impossible changes according to the needs and peculiarities of each school. Publishers, in turn, have no interest in changing this model to purchase textbooks for basic education by the federal Government, for being quite lucrative.

As Rossini and Gonzalez (2012), average unit prices of the books have grown substantially in recent years, while the quantities purchased increased so if could bargain a lower price due to the large volume of purchase or even provide a way to ensure more autonomy to teachers who choose such work because they would buy the copyright and not just printed copies of the materials.

The authors are hostages of the big publishing houses, because it is necessary money to publicize his books on the market and include them in his own edict, and catalog so that teachers of basic education can choose their books. So, the editors ensure the sales of chosen books copies, but they do not pay the copyright to the Government so that the books can be changed or scanned. Law No. 9,610/1998 (BRASIL, 1998), the Brazilian copyright law, there are two distinct beams: moral rights (article no 24 which guarantees rights of personality, or is inalienable, unremitting, and indispensable) and economic rights (transferable to publishers).

If the Government undertakes the acquisition of rights by the use of the work directly with the authors, these would get more and even the teachers would have the freedom to tailor works, simply reference the author of the content, including being possible to print them in graphic and distribute to students for a lower cost.

It would still be possible to spread a culture of use of OER in basic education through the inclusion of students in the chain of authorship, whether in the regular curriculum-related activities, is encouraging autonomous initiatives of content production in complementary activities.

In the case of Brazil, the higher education there is a policy of acquisition of books for each student, so higher education institutions acquire copies of books adopted in the disciplines for libraries, but the bibliographical works are not updated constantly due to the high prices of the copies, which also drove students away from buying books and took them to illegal copies (AMIEL, 2012, p. 26).

With the idea of OER, arise new possibilities of teaching rather than simply delete the printed material. The expansion of e-Learning made possible the availability of digital resources open or not under various settings (AMIEL, 2012, p. 26). This access to the use of new media has facilitated the production and reproduction of educational resources and cultural assets. Teachers and students can take on the role of authors of their own study materials or constructive critics (PRETTO, 2010).

Opal (2011) suggests get opportunities with open practices involving the creation, use and management of OER's, with a view to innovation and improving the education quality. Already 
Amiel (2012) emphasizes the sharing, because besides search, adapt and use OER's, the original author and material changes are disseminated to hundreds of people. As Shneiderman (2002) mentions the cycle generated by sharing, because the resources provide opportunities for others to use these resources and generate new educational possibilities.

The principles of OER's were inspired in the FLOSS project, whose main idea is in the development and sharing of applications without the need to pay a license for its use. Taurion (2004) and Matias et al. (2016) feature the freedoms of open source software, since this must meet the four basic freedoms of the GPL:

- Freedom no 0: freedom to run the software for any purpose;

- Freedom no 1: freedom to study how the program works and adapt it to your needs, having as a prerequisite the access to the source code;

- Freedom $n^{\circ} 2$ : the freedom to redistribute copies so you can help your neighbor;

- Freedom $\mathrm{n}^{\circ}$ 3: the freedom to improve the program, and release your improvements, so that the whole community benefits from them.

Already in relation to the OER's, Matias et al. (2016) feature 5R's freedoms of Mallmann and Jacques (2015): retention, reuse, review, remix and redistribution. About to retention permission to download and store file copies in digital format or not. Already the reuse is the ability to use and reuse the resource as often as you like; while the review enables other people report improvements or proposals for improvements of materials in such a way as to ensure the credit to the original authors and ensure compliance with the licensing rules of the resource. With respect to the remix, that promotes the adaptation of the materials, while the redistribution allows users to distribute copies of the material.

\subsection{Teaching Sociology}

According to Pereira (2009), the teaching of Sociology in high school faces several challenges, such as the training of teachers (holders of discipline without training in the Social Sciences area), the high workload of the public school teachers and low wages. In addition, one can also consider the need of appropriate methodologies to the contents of the area.

Pereira (2009) also highlights a devaluation culture of Sociology by students and other members of the school community, evidenced in places that express that discipline fail.

Ferreira et al. (2015) cites a lack of teaching materials of Sociology to the high school, digital educational resources (DER) or textbooks, although the NCPHS distribute books and websites as material support, but the NCPHS to 2015 of Sociology (BRASIL, 2014) suggests only six books printed and digital available for choice of four teachers from the public network.

The DER also stores provide few resources in formats of simulations or educational software in the field of Sociology for any level of education, since most of the materials found are videos or texts in PDF format on subjects alone or biographies of authors.

\subsection{Parameters and guides of education in Brazil}


The National Curricular Parameters (NCP) come from discussions between the various sectors of the academic community and society, and were initially intended for elementary education in 1998 (ABREU, 2011).

Already in 2000, the publication of National Curriculum Parameters for high school (NCPHS), so it was possible trying to specifically for the final series of basic education, high school, and to the following aspects: contextualization and interdisciplinarity in teaching approaches. In this way, the content to be explored in must be situated, located, significant in its practices and relationships, bridges possible, with other areas (ABREU, 2011).

According to Abreu (2011), such documents still suggest the construction of citizenship, as well as makes it necessary to redesign the curriculum linked to new forms of learning content, through skills and abilities. This motivates a review on traditional education stance, so as not to be limited to formal and informal knowledge.

The NCPHS (BRASIL, 2000) are divided into three areas of learning under the perspective of interdisciplinarity: Languages, Codes and Their Technologies; Natural Sciences, Mathematics and Technology; and the Humanities and its Technologies. This last area comprises the discipline of Sociology. Such Division has the goal of providing the contextual relationships between disciplines Affairs before isolated treatment. The NCPHS are formed by abilities and skills which served as basement to analysis of the open textbooks.

The Guide of Textbook National Program was also another official document used to define the evaluation criteria of this research. Thus, some criteria used in the analysis of the Textbooks National Program were adequate to be used in the evaluation of open textbooks. Such criteria are known to evaluators and teachers, as well as serve as basement to textbook evaluation periodically. The research, in turn, used the area guide of Sociology of 2015 (BRASIL, 2014), whose criteria are described in the next section.

\section{METHODOLOGY}

The research has surveyed the bibliographies related to the subject in order to identify the materials already elaborated, mainly the academic works and books, in order to guarantee an extended view of the subject matter researched and to detect the gaps in the completed studies (GIL, 2002).

In addition, an online survey was conducted to identify the open textbooks repositories and to select open textbooks from Sociology for High School, published in Portuguese and registered with the International Standard Book Number (ISBN).

A total of 41 repositories of OER's were identified, including some specific to open textbooks, such as the Flat World Knowledge repository and the Latin Project repository (intended for higher education and mostly Spanish). Thus, only the Educational Portal of the Brazilian State of Paraná presented open textbooks with the characteristics described in the preceding paragraph.

The open textbooks were evaluated according to the criteria based on the competencies and guiding abilities of the NCPHS of the discipline under analysis (BRASIL, 2000), the Textbook Guide of the Textbooks National Program of 2015 (BRASIL, 2014) and the 5R's freedoms 
(MALLMANN \& JACQUES, 2015), whose evaluation of each material occurred through its complete reading and identification of the presence or absence of the evaluative criteria of table 1.

Table 1: Evaluation criteria of open textbooks suitable from Oliveira and Abreu (2016).

\begin{tabular}{|c|c|c|}
\hline Level & ID & Description \\
\hline \multirow[t]{2}{*}{$\begin{array}{l}\text { Representation } \\
\text { and } \\
\text { communication }\end{array}$} & $\mathrm{CO1}$ & $\begin{array}{l}\text { Identify, analyze and compare the different discourses about reality: } \\
\text { the explanations of the Social Sciences, supported by the various } \\
\text { theoretical paradigms, and those of common sense. }\end{array}$ \\
\hline & $\mathrm{CO} 2$ & $\begin{array}{l}\text { Produce new discourses on the different social realities, based on } \\
\text { observations and reflections. }\end{array}$ \\
\hline \multirow[t]{3}{*}{$\begin{array}{l}\text { Research and } \\
\text { understanding }\end{array}$} & $\mathrm{CO3}$ & $\begin{array}{l}\text { Build tools for a better understanding of everyday life, broadening } \\
\text { the "world view" and the "horizon of expectations" in interpersonal } \\
\text { relationships with various social groups. }\end{array}$ \\
\hline & $\mathrm{CO4}$ & $\begin{array}{l}\text { To construct a more critical view of the cultural industry and the } \\
\text { mass media, evaluating the ideological role of marketing as a } \\
\text { strategy to persuade consumers and the voters themselves. }\end{array}$ \\
\hline & $\mathrm{CO5}$ & $\begin{array}{l}\text { Understand and value the different cultural manifestations of } \\
\text { ethnicities and social segments, in order to preserve the right to } \\
\text { diversity as an aesthetic, political and ethical principle that } \\
\text { overcomes conflicts and tensions in the world today. }\end{array}$ \\
\hline \multirow[t]{2}{*}{$\begin{array}{l}\text { Socio-cultural } \\
\text { contextualizatio } \\
\text { n }\end{array}$} & CO6 & $\begin{array}{l}\text { Understand the transformations in the world of work and the new } \\
\text { qualification profile required, generated by changes in the economic } \\
\text { order. }\end{array}$ \\
\hline & $\mathrm{CO}$ & $\begin{array}{l}\text { To build social and political identity, so as to enable the exercise of } \\
\text { full citizenship, in the context of the rule of law, acting in order to } \\
\text { effectively reciprocate rights and duties between the public and the } \\
\text { citizen, and also between the different groups. }\end{array}$ \\
\hline $\begin{array}{l}\text { Miscellaneous } \\
\text { legal criteria }\end{array}$ & $\mathrm{COB}$ & $\begin{array}{l}\text { It verifies if the book respects the Brazilian legislation in force and } \\
\text { other international norms (Federal Constitution, Law of Guidelines } \\
\text { and Bases of Education, Statute of the Child and Adolescent and the } \\
\text { National and International Guidelines). }\end{array}$ \\
\hline $\begin{array}{l}\text { Conceptual } \\
\text { theoretical }\end{array}$ & CO9 & $\begin{array}{l}\text { Relates to the quality of the theoretical-conceptual references were } \\
\text { elaborated to help the evaluator analyze whether, in the whole, the } \\
\text { work in judgment values by the rigor in the presentation of concepts } \\
\text { and theoretical paradigms of the field of Social Sciences, whether in } \\
\text { contributions of the classic period or more recently. }\end{array}$ \\
\hline \multirow[t]{2}{*}{$\begin{array}{l}\text { Didactic- } \\
\text { pedagogical }\end{array}$} & C10 & $\begin{array}{l}\text { The material is more content oriented. It evaluates the language, } \\
\text { arguments and strategies used by authorship in the basic text of the } \\
\text { book to carry out the mediation between scientific knowledge and } \\
\text { scholastic knowledge. }\end{array}$ \\
\hline & C11 & $\begin{array}{l}\text { It is more focused on activities and exercises. It judges whether the } \\
\text { proposed learning activities mobilize different capacities, verify if } \\
\text { they are consistent with the approach and content proposed in the } \\
\text { book, and verify if they actually help in achieving the learning } \\
\text { objectives. }\end{array}$ \\
\hline
\end{tabular}




\begin{tabular}{|c|c|c|}
\hline $\begin{array}{l}\text { Picture } \\
\text { evaluation }\end{array}$ & C12 & $\begin{array}{l}\text { It considers if the images, photos, illustrations, graphs, tables and } \\
\text { maps present in the work evaluated range from the criteria related } \\
\text { to clarity of exhibition and the immediate identification of credits } \\
\text { and sources, to criteria evaluating the ability of images to aid in } \\
\text { learning. Arousing reflection and not linking stereotypes of any } \\
\text { nature, religious content or trademark. }\end{array}$ \\
\hline $\begin{array}{l}\text { Publishing and } \\
\text { visual aspects }\end{array}$ & C13 & $\begin{array}{l}\text { Relates to spelling and the consistency and accuracy of information } \\
\text { about book, site, and document references. Some questions in this } \\
\text { section address graphic design, which should favor student learning } \\
\text { and facilitate book handling. }\end{array}$ \\
\hline $\begin{array}{l}\text { Teacher's } \\
\text { manual }\end{array}$ & C14 & $\begin{array}{l}\text { There is a Teacher's Manual and if it really fulfills the objective of } \\
\text { guiding him about the presuppositions that underpinned the } \\
\text { elaboration of the book and the possibilities of its use, with } \\
\text { additional suggestions that qualify the lesson, respecting the } \\
\text { teaching autonomy. }\end{array}$ \\
\hline \multirow[t]{5}{*}{ OER } & C15 & It releases retention from digital or non-material copies. \\
\hline & C16 & It allows reuse for other educational contexts. \\
\hline & C17 & It consents review of materials by users. \\
\hline & C18 & It enables remixing of content. \\
\hline & C19 & It supports the redistribution of materials to other users. \\
\hline
\end{tabular}

The criteria used for evaluation took into account the skills and abilities defined by the NCPHS of Sociology (BRASIL, 2000), the Guide to the National Textbook Program of 2015 (BRASIL, 2014) and the 5R's freedoms (MALLMANN \& JACQUES, 2015). The results and considerations were noted and will be presented in the next section, so as to evaluate the only work in accordance with the scope of this research, since other works were discarded from the analysis because it did not have ISBN number, it was not in Portuguese language, the content was not directed to high school or were not intended for the discipline of Sociology (LORENSETTI et al., 2006).

\section{RESULTS AND DISCUSSION}

When assessing the open textbooks identified with the criteria in Table 1, it is possible to perceive that criterion $\mathrm{CO} 1$ is satisfied when comparisons are presented between different points of view based on different theorists, as well as the comparison with the common sense soon in the second page of the First unit. While the other criterion of the level of representation and communication ( $\mathrm{CO} 2$ ) is basically satisfied through activities, of questions motivating reflection within the text or even instigated by authors who present reflective aspects about the theory during the course of the unit until culminating in activity.

Already the level of Investigation and understanding is composed by the criteria C03, C04 and C05. C03 is used to verify the authors' search to present the different social, religious, ethnic and other groups and their forms of interrelationship. Including proposals of activities for the students to interview at least three religious leaders, with a view to providing a Better 
understanding of everyday life, broadening the "world view", the "horizon of expectations", especially in chapters 4, 5 and 6 of the work under analysis.

Like the previous criterion, $\mathrm{CO} 4$ is also satisfied and perceived in chapters 7 and 8, through the analyzes made between historical facts and the means of communications used to construct the mass opinion in favor of interests of the ruling class. Thus, C05 is also attended, when the authors seek to interpret, generate reflections on the presentations of cultural manifestations of ethnicities and social segments throughout history, as well as the rights conquered and until now available in the current legislation that guarantees the diversity of manifestations based In ethical precepts that overcome conflicts and tensions in today's world.

About the level of sociocultural contextualization, criteria C06 and C07 are also met. C06 is perceived when the transformations in the world of work and the new qualification profile required are presented, generated by changes in the economic order in chapters 9 and 10, while C07 is explained in chapters 12, 13, 14 and 15, when it is shown The construction of social and political identity, so as to enable the exercise of full citizenship, in the context of the rule of law.

Regarding the level of various legal aspects, criterion C08 is promptly met by the work when referring to the main legal precepts in force in our country such as: Federal Constitution, Law of Directives and Bases of Education and Child and Adolescent Statute. While NCPHS are also met, however, criteria $\mathrm{CO} 1$ to $\mathrm{CO} 7$ are strictly focused on such a standard, so the description of C08 excludes NCPHS.

The main references of the Social Sciences and related subjects are also presented, used and referenced in the work, in such a way to reach criterion 09 (level of theoretical conceptual criteria). In this way, it is possible to cite some works such as: (ROUSSEAU, 1999; MARX, 1985; MARX, 1987; MARX, 1989; MARX, 1996; FERNANDES, 1978A; FERNANDES, 1978B; ENGELS, 1978; FREYRE, 2001; PRADO JÚNIOR, 2000; COMTE, 1978).

The level of didactic-pedagogical criteria is formed by criteria C10 (focused on content) and C11 (for exercises). The language, the arguments and the strategies are cohesive in relation to the achievement of the objectives established in each unit of the work, since it is directed to the High School and uses an easy language, based on theoretical arguments presented in the work and with strategies easy to be Used and adapted to the different study contexts.

The suggested activities seek to stimulate the writing of argumentative and descriptive texts on the subjects studied in each unit, as well as suggesting research on other materials and conducting interviews with people from society directly linked to historical, political or religious facts.

While at the level of image evaluation criteria, C12 is also achieved by the material, since the tables, maps, images, figures and other illustrations are visible and do not present problems for perfect visualization by the readers.

Criterion C13 (level of editorial criteria and visual aspects) is also satisfied by the analyzed material, because it is in compliance with the normative grammatical and orthographic of the Portuguese language, as well as there is synchronism of the graphic design of the material, with a view to creating a Pleasant layout to the students reading without strong colors or which does not match of the general context of the work. 
At the Teacher Manual level, criterion C14 is contemplated with an electronic page (http://www.sociologia.seed.pr.gov.br/) and with a didactic manual to the teacher and other digital resources as videos to support the teachers.

The criteria of the OER's level (C15 A C19) are satisfied with the possibility of retention, use, reuse, revision, remixing and redistribution, but the PDF format, in which the file is made available, although the file is not encrypted, it allows the format to be edited by some applications, but does not guarantee the established formatting of the original document.

Therefore, in general, it is noticed that all the analyzed criteria are attended or in a partial way, whose alterations of these materials can make them as good or better than many materials under proprietary licenses and still with possibility of adaptation to the needs of the teachers, the regional contexts in which they are inserted.

\section{CONCLUSION}

The elaboration of the open textbooks evaluation criteria based on the adequacy of the Sociology CNPHS (BRASIL, 2000), the Guide of the Textbook National Program of 2015 (BRASIL, 2014) and the 5R's freedoms (MALLMANN \& JACQUES, 2015) can become a reference in the analysis of open textbooks by teachers or even an institutional policy of the Brazilian Ministry of Education in order to reduce the costs with the acquisition of physical copies of textbooks, which often prevent the changes by the teachers, being this is a real need for the works to meet the diverse regional contexts of our country.

In addition, the criteria can also become the references for the preparation of open textbooks by teachers who wish not only to consume the didactic products, but also to become producers of their own materials, either from the adequacy of materials available under licenses of use and adequacy, or even the elaboration from the first to the last chapter in a contextualized way and with unpublished texts, but dealing with the necessary grid the said series.

It was also perceived the quality of a free and available work for use and adaptations after the careful analysis of the open textbooks, whose teachers and managers are often unaware of the possibility of having good quality materials, free and easy to be distributed, updated and Used in different ways (virtual or printed, in whole or in part).

\section{REFERENCES}

Abreu, K. F. (2011). Concepções de leitura e de texto subjacentes às provas de vestibular: constatações e implicações para o ensino da língua espanhola. 2011. 271f. Dissertação (Programa de Pós-Graduação em Linguística) - UFC, Fortaleza.

Amiel, T. (2012). Educação aberta: configurando ambientes, práticas e recursos educacionais. In: SANTANA, BIANCA; ROSSINI, CAROLINA; PRETTO, NELSON DE LUCCA (Organizadores). Recursos Educacionais Abertos: Práticas Colaborativas E Políticas Públicas. Salvador: Edufba; São Paulo: Casa da Cultura Digital.

Brasil. (2014). Guia de livros didáticos: PNLD 2015 - Sociologia -Ensino Médio. Brasília: Ministério da Educação, Secretaria de Educação Básica. Disponível em: 
http://www.fnde.gov.br/arquivos/category/125-guias?download=9011:pnld-2015sociologia. Acesso em: 12 de outubro de 2015.

. (2012). Livros didáticos. Brasília: FNDE. Disponível em: http://www.fnde.gov.br/ index.php/pnld-dados-estatisticos. Acesso em: 10 de outubro de 2015.

- (2000). Parâmetros Curriculares Nacionais para o Ensino Médio (PCNEM) - Parte IV Ciências Humanas e suas Tecnologias. Brasília: Ministério da Educação. Disponível em: http://portal.mec.gov.br/seb/arquivos/pdf/cienciah.pdf. Acesso em: 12 de outubro de 2015.

(1998). Lei $n^{\circ}$ 9.610/1998. Brasília, DF: Senado. Disponível em: http://www.planalto.gov.br/ccivil_03/leis/L9610.htm. Acesso em: 12 de outubro de 2015.

Comte, A. (1978). Sociologia. Organização e tradução de Evaristo de Morais Filho. São Paulo: Ática.

Engels, F. (1978). A origem da família, da propriedade privada e do Estado. Rio de Janeiro: Civilização Brasileira.

Fernandes, F. (1978a). Fundamentos da explicação sociológica. 3a ed. Rio de Janeiro: LTC. . (1978b). A integração do negro na sociedade de classes. Vol. I e II. São Paulo: Ática.

Freyre, G. (2001). Casagrande \& senzala - introdução à história da sociedade patriarcal no Brasil. Rio de Janeiro: Record.

Gil, A. C. (2002). Como elaborar projetos de pesquisa. 4. Ed. São Paulo: Atlas.

Lorensetti, E.; Picanço, K. C. L.; Iwaya, M.; Ferreira, S. M.; Silva, S. A. S.; Pilão, V. (2006). Sociologia. Curitiba: SEED-PR.

Mallmann, E. M.; Jacques, J. S. (2015). Recursos Educacionais Abertos (REA) na Pedagogia do eLearning. In: ROSADO, L. A. S.; FERREIRA, G. M. S.; Educação e tecnologia: parcerias. Vol. 4. Rio de Janeiro: Editora Universidade Estácio de Sá.

Marx, K. (1985). O Capital: crítica da economia política. São Paulo: Nova Cultural.

. (1987). O Manifesto comunista. URSS: Edições Progresso.

. (1989). Manuscritos econômicos-filosóficos. Lisboa: Edições 70.

. (1996). A ideologia alemã. São Paulo: Hucitec.

Matias, P. H. B.; Oliveira, F. K.; Abreu, K. F.; Mello, H. M. (2016). Ambiente de compartilhamento de REAs: uma proposta de modelagem, implementação e modelo de negócio. Revista Semiárido De Visu, v. 4, n. 1, p. 18-31.

Oliveira, F. K.; Abreu, M. F. (2016). O ensino de Sociologia baseado em livros didáticos abertos. In: RAABE, A. L. A.; GOMES, A. S.; BITTENCOURT, I. I.; PONTUAL, T. Educação Criativa: Multiplicando experiências para a aprendizagem. Recife: Pipa Editora.

Oliveira, F. K. (2010). O vídeo pela Internet como ferramenta educacional no ensino da Geometria. 2010. 102f. Dissertação (Programa de Pós-Graduação em Ciências da Computação) - UECE, Fortaleza.

Opal, B. (2011). OER: Shifting Focus from Resources to Practices The OPAL Report 2011. Disponível em: http://goo.gl/iM3Z19. Acessado em: 10 de outubro de 2015.

Ortellado, P. (2009). Uma política de direito autoral para o livro didático. São Paulo: Ação 
Educativa Observatório da Educação, 2009 (Desafios da Conjuntura, v.1, n.27, ago. 2009).

Pereira, L. H. (2009). Por uma sociologia da sociologia no Ensino Médio. In: Congresso Brasileiro de Sociologia, 14, 2009, Rio de Janeiro. Anais. Rio de Janeiro: Sociedade Brasileira de Sociologia.

Prado Júnior, C. (2000). Formação do Brasil contemporâneo. 23ạ ed. São Paulo: Brasiliense.

Pretto, N. (2010). Redes colaborativas, ética hacker e educação. Educação em Revista, v. 26, n. 3, p. 305-316.

Rossini, C. \& Gonzalez, C. (2012). REA: o debate em política pública e as oportunidades para o mercado. SANTANA, B.; ROSSINI, C.; PRETTO, N. L. Recursos educacionais abertos: práticas colaborativas e políticas públicas, v. 1, p. 35-70.

Rousseau, J. J. (1999). Do contrato social. São Paulo: Nova Cultural.

Shneiderman, B. (2002). Leonardo's laptop. Cambridge, MA: MIT Press.

Taurion, C. (2004). Software Livre - Potencialidades e Modelos de Negócios. 1ạ ed. São Paulo: Brasport. 